\title{
THE INFLUENCE OF HEAVY METALS CONTAMINATION IN SOIL ON THE COMPOSITION OF SOME WILD EDIBLE MUSHROOMS
}

\author{
MAGDALENA MITITELU $^{1 \#}$, MANUELA GHICA ${ }^{2 \#}$, ANA CORINA IONIŢA ${ }^{1}{ }^{*}$, ELENA MOROŞAN $^{1}$ \\ ${ }^{I}$ Department of Clinical Laboratory and Food Safety, Faculty of Pharmacy, University of Medicine and Pharmacy "Carol \\ Davila”, Bucharest, Romania \\ ${ }^{2}$ Department of Biostatistics, Faculty of Pharmacy, University of Medicine and Pharmacy "Carol Davila", Bucharest, Romania
}

*corresponding author: ana_corina_ionita@yahoo.com

${ }^{\#}$ Authors with equal contributions

Manuscript received: December 2018

\begin{abstract}
The concentrations of seven trace elements (cadmium, cooper, zinc, lead, chromium, iron and nickel) and two macroelements (calcium and magnesium) were determined in two edible species of mushrooms (Boletus edulis and Hymenochaete rubiginosa) collected from adjacent zones of two urban areas. The concentration of the chemical elements was determined by atomic absorption spectroscopy. In the area with high degree of soil contamination the mushrooms samples presented the highest contamination with heavy metals.
\end{abstract}

\section{Rezumat}

$\mathrm{Cu}$ ajutorul spectroscopiei de absorbţie atomică s-a determinat concentrația a şapte metale grele (cadmiu, cupru, zinc, plumb, crom, fier şi nichel) şi a două macroelemente (calciu şi magneziu) din două specii de ciuperci comestibile (Boletus edulis şi Hymenochaete rubiginosa) recoltate din împrejurimile a două zone urbane. În zonele cu nivel mare de poluare a solului s-a constatat o contaminare crescută cu metale grele şi în probele de ciuperci recoltate.

Keywords: heavy metals, atomic absorption spectrometry, Boletus edulis, Hymenochaete rubiginosa

\section{Introduction}

The soil pollution with heavy metals may pose risks to human health by drinking contaminated water, reduction of food quality (safety and marketability) and reduction of the land usability for agricultural production causing food insecurity.

The soil contamination with heavy metals can originate from a wide variety of anthropogenic sources in the form of metal mine tailings, disposal of high metal wastes in improperly protected landfills, leaded gasoline and lead-based paints, land application of fertilizer, animal manures, pesticides, coal combustion residues, petrochemicals, the aerial emission of lead from the combustion of petrol containing tetraethyl lead and atmospheric deposition. Increased concentrations of zinc and cadmium are also increased in soils adjacent to roads, the sources being tyres, and lubricant oils [1-5].

Mushrooms, comparing to green plants, are capable of bio-accumulating more heavy metals found in the surface soil level. Many vegetarians consume them as a source of protein instead of meat or fish. Their cultivation is not common and edible species are mostly collected from nature, being also important as therapeutic vegetal resources [2, 4].

Several studies sustain the mushrooms capacity to concentrate several elements from the environment including heavy metals. For example, the amount of mercury in mushrooms (Boletus edulis) from Krompachy (mercury plant, Czech Republic) was $3200 \mu \mathrm{g} / \mathrm{g}$ dry matter, where the amount of this element for low contaminated areas was $2300 \mu \mathrm{g} / \mathrm{g}[3,4]$.

The contamination of mushrooms depends of many factors including the type of species and the level of soil contamination where the mushrooms grow. Scientific literature sustains the bioindicator potential of mushrooms, which can be used in environmental protection due to their composition correlated with the field pollution level for some heavy metals [6$10]$.

Several studies are mentioning the commonly used methods for heavy metals determination in soils, phosphorus rocks, seawater, plants, biologic materials, steels and cast iron such as inductive coupled plasma mass spectrometry, inductive coupled plasma - atomic emission spectrometry, atomic absorption spectrometry with flame or electrothermal atomization, spectrophotometric methods, X-ray fluorescence, electrochemically with ultra-microelectrodes, anodic stripping voltammetry [11-16].

The study aims to determine the level of calcium, magnesium and some heavy metals in the soil of two urban areas and two edible mushrooms species growing in the same ground. The correlation between 
the chemical composition of soil and the mushrooms was also considered for analyses in order to identify potential bioindicators of heavy metal soil pollution.

\section{Materials and Methods}

The concentrations of seven trace elements (cadmium, cooper, zinc, lead, chromium, iron and nickel) and two macroelements (calcium and magnesium) were determined in both two edible species of mushrooms (Boletus edulis and Hymenochaete rubiginosa) and respectively soil samples where the mushrooms were grown.

The mushrooms were collected from adjacent zones of two neighbouring cities (noted soil 1 and soil 2) during September - November 2017. The samples from the two species of mushrooms were analysed from each urban area by atomic absorption spectrometry. In order to analyse the concentrations of heavy metals, the mushrooms samples were washed, hashed, dried at $105^{\circ} \mathrm{C}$ for 24 hours and mineralized by the wet digestion method (mixture of $66 \% \mathrm{HNO}_{3}$ and $98 \%$ $\mathrm{H}_{2} \mathrm{SO}_{4}$ ). The soil samples were dried and mineralised by wet digestion method too. All samples were homogenised and $2 \mathrm{~g}$ of homogenate were weighed, placed in vessels in the ash unit with $10 \mathrm{~mL} 65 \%$

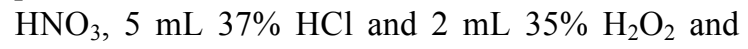
gradually heated (Velp DK-6 Heating Digester) $\left(150^{\circ} \mathrm{C}\right.$ for $1 \mathrm{~h}, 200^{\circ} \mathrm{C}$ for $2 \mathrm{~h}, 250^{\circ} \mathrm{C}$ for $1 \mathrm{~h}, 300^{\circ} \mathrm{C}$ for 2 hours). The solutions were allowed to cool at room temperature, transferred into $25 \mathrm{~mL}$ volumetric flasks and diluted with ultra-distilled water $[6,7]$.

All used reagents were of analytical grade (Merck). The solutions were analysed with an atomic absorption spectrophotometer Shimadzu AA 6300 (air/acetylene flame) in order to determine the heavy metals concentration: cadmium $(\lambda=228.8 \mathrm{~nm})$, cooper $(\lambda=$ $324.7 \mathrm{~nm})$, zinc $(\lambda=213.9 \mathrm{~nm})$, lead $(\lambda=217 \mathrm{~nm})$, chromium $(\lambda=357.9 \mathrm{~nm})$, iron $(\lambda=378 \mathrm{~nm})$ and nickel $(\lambda=232 \mathrm{~nm})$, calcium $(\lambda=422.7 \mathrm{~nm})$ and magnesium $(\lambda=285.2 \mathrm{~nm})$. A blank digestion solution was made for comparison. A standard solution for each element under investigation was prepared and used for calibration. The determinations were performed in triplicate for each solution. Results are expressed as Mean $\pm \mathrm{SD}$ (standard deviation).

\section{Statistical analyses}

Biostatistical analysis was implemented using the $\mathrm{R}$ statistical software ( $\mathrm{R}$ version 3.5.3). The multivariate analysis of the variance (MANOVA) was utilized to analyse two factors (mushrooms and area) and nine chemical elements found in mushrooms, using bootstrap approach. We analysed each dependent variable in relation to both factors through the twoway analysis of variance (ANOVA) and we also found important descriptive statistics and confident intervals for the mean. Our data were verified for normality using Shapiro-Wilk's test and that data conformed to the assumption of normality. We used, also, the t-student to find if there is a difference between samples for different concentration of some chemical elements and the correspondent samples from the 2 type of soil. Finally, we analysed the influence of the concentration of some chemical elements from the soil on the concentration determined in the mushrooms. Statistical significance level was considered at $5 \%(\mathrm{p}=0.05)$ [17-19].

The normal levels for certain heavy metals in soil in respect to Romanian legislation according to Order no 765/1997 of the Ministry of Waters and Forests [20] are: cadmium $1 \mu \mathrm{g} / \mathrm{g}$, cooper $20 \mu \mathrm{g} / \mathrm{g}$, zinc $100 \mu \mathrm{g} / \mathrm{g}$, lead $20 \mu \mathrm{g} / \mathrm{g}$, chromium $30 \mu \mathrm{g} / \mathrm{g}$ and nickel $20 \mu \mathrm{g} / \mathrm{g}$.

\section{Results and Discussion}

The calcium, magnesium and heavy metal concentrations in analysed samples are presented in Tables I - IV. The relation between the soil concentration and the mushrooms level of the analysed chemical elements are presented in Figure 1.

The data presented in Tables I - IV revealed that there were some differences between the chemical elements concentrations in soil samples collected from different areas due to the industrial activities specific of each urban zone. We observed that heavy metals concentrations in soil samples overtake normal value. The concentrations of cadmium, cooper, nickel, lead and zinc in the soil samples from urban area 2 (soil 2) were exceeding the normal range. The highest concentrations of cooper $(88.3 \pm 3.1 \mu \mathrm{g} / \mathrm{g})$, chromium $(43.1 \pm 1.5 \mu \mathrm{g} / \mathrm{g})$ and zinc $(81.2 \pm 2.7 \mu \mathrm{g} / \mathrm{g})$ were detected in the soil samples from urban area 1 (soil 1).

Table I

Macroelements concentrations in the analysed mushroom and soil samples

\begin{tabular}{|l|c|c|}
\hline \multicolumn{1}{|c|}{ Sample } & Calcium & Magnesium \\
\hline Soil 1 (S1) & $2900.02 \pm 2.4 \mathrm{ppm}$ & $2300.01 \pm 2.8 \mathrm{ppm}$ \\
\hline Soil 2 (S2) & $3400.02 \pm 1.3 \mathrm{ppm}$ & $2800.03 \pm 2.5 \mathrm{ppm}$ \\
\hline Boletus sample from S1 & $0.62 \pm 2.6 \mu \mathrm{g} / \mathrm{g}$ & $0.71 \pm 1.7 \mu \mathrm{g} / \mathrm{g}$ \\
\hline Boletus sample from S2 & $1.05 \pm 1.3 \mu \mathrm{g} / \mathrm{g}$ & $0.65 \pm 1.1 \mu \mathrm{g} / \mathrm{g}$ \\
\hline Hymenochaete sample from S1 & $0.87 \pm 1.2 \mu \mathrm{g} / \mathrm{g}$ & $1.22 \pm 2.2 \mu \mathrm{g} / \mathrm{g}$ \\
\hline Hymenochaete sample from S2 & $0.44 \pm 3.1 \mu \mathrm{g} / \mathrm{g}$ & $0.75 \pm 2.5 \mu \mathrm{g} / \mathrm{g}$ \\
\hline
\end{tabular}


FARMACIA, 2019, Vol. 67, 3

Table II

Heavy metals concentration (reported at dry weight)

in soil samples

\begin{tabular}{|l|c|c|c|}
\hline $\begin{array}{c}\text { Chemical } \\
\text { element }\end{array}$ & $\begin{array}{c}\text { Normal value } \\
(\boldsymbol{\mu} \mathbf{g} / \mathbf{g})\end{array}$ & $\begin{array}{c}\text { Soil 1 } \\
(\boldsymbol{\mu} \mathbf{g} / \mathbf{g})\end{array}$ & $\begin{array}{c}\text { Soil 2 } \\
(\boldsymbol{\mu} \mathbf{g} / \mathbf{g})\end{array}$ \\
\hline Iron & - & $42.4 \pm 1.4$ & $55.1 \pm 3.4$ \\
\hline Cooper & 20 & $88.3 \pm 3.1$ & $63.2 \pm 2.2$ \\
\hline Cadmium & 1 & $0.3 \pm 1.1$ & $6.1 \pm 2.8$ \\
\hline Chromium & 30 & $43.1 \pm 1.5$ & $30.7 \pm 1.7$ \\
\hline Nickel & 20 & $20.9 \pm 2.1$ & $34.2 \pm 1.9$ \\
\hline Lead & 20 & $17.9 \pm 2.5$ & $35.6 \pm 3.3$ \\
\hline Zinc & 100 & $81.2 \pm 2.7$ & $271.4 \pm 3.5$ \\
\hline
\end{tabular}

Table III

Heavy metals concentration (reported at dry weight) in Boletus edulis samples

\begin{tabular}{|l|c|c|}
\hline \multicolumn{1}{|c|}{ Element } & Soil 1 $(\boldsymbol{\mu} \mathbf{g} / \mathbf{g})$ & Soil $\mathbf{2}(\boldsymbol{\mu} \mathbf{g} / \mathbf{g})$ \\
\hline Iron & $10.5 \pm 3.7$ & $8.72 \pm 2.8$ \\
\hline Cooper & $9.24 \pm 2.2$ & $7.3 \pm 2.1$ \\
\hline Cadmium & $0.33 \pm 2.4$ & $3.9 \pm 3.1$ \\
\hline Chromium & $4.21 \pm 1.7$ & $3.1 \pm 1.2$ \\
\hline Nickel & $0.32 \pm 1.6$ & $0.71 \pm 1.9$ \\
\hline Lead & $0.85 \pm 2.8$ & $1.4 \pm 1.4$ \\
\hline Zinc & $1.9 \pm 3.5$ & $2.61 \pm 3.4$ \\
\hline
\end{tabular}

Table IV

Heavy metals concentration (reported at dry weight) in Hymenochaete rubiginosa samples

\begin{tabular}{|l|c|c|}
\hline Chemical element & Soil 1 $(\boldsymbol{\mu} \mathbf{g} / \mathbf{g})$ & Soil $\mathbf{2}(\boldsymbol{\mu} \mathbf{g} / \mathbf{g})$ \\
\hline Iron & $7.6 \pm 2.9$ & $9.2 \pm 2.4$ \\
\hline Cooper & $11.82 \pm 3.4$ & $8.31 \pm 1.5$ \\
\hline Cadmium & $1.21 \pm 2.7$ & $5.11 \pm 1.2$ \\
\hline Chromium & $6.5 \pm 2.2$ & $3.3 \pm 2.6$ \\
\hline Nickel & $0.22 \pm 3.5$ & $0.68 \pm 2.1$ \\
\hline Lead & $0.31 \pm 3.2$ & $1.51 \pm 3.3$ \\
\hline Zinc & $1.43 \pm 2.9$ & $2.54 \pm 3.4$ \\
\hline
\end{tabular}

There were also some variations of elements concentration in mushroom samples analysed. The highest concentrations of chromium $(6.5 \pm 2.2 \mu \mathrm{g} / \mathrm{g})$ were detected in Hymenochaete rubiginosa samples from soil 1 where was founded a high concentration of chromium in soil, lead $(1.51 \pm 3.3 \mu \mathrm{g} / \mathrm{g})$ and cadmium $(5.11 \pm 1.2 \mu \mathrm{g} / \mathrm{g})$ in high concentrations were detected in Hymenochaete rubiginosa samples from soil 2, in change, in Boletus edulis samples from soil 2 (Table III) were detected the highest amounts of nickel $(0.71 \pm 1.9 \mu \mathrm{g} / \mathrm{g})$ and zinc $(2.61 \pm 3.4 \mu \mathrm{g} / \mathrm{g})$. The samples belonging to the soil 2 presented also high concentrations in lead, cadmium, nickel and zinc (Table II).
Using the multivariate analysis, we analysed the simultaneous research of the combination of multiple variables. The following characteristics were selected for the analyses: number and type of factors (independent variables) and number and type of dependent variables.

For the studied experiment we considered 2 factors presented through categorical type variables. The first factor characterizes the type of fungus studied (Boletus and Hymenochaete) and the second factor characterizes the area from which they were collected (noted by "soil 1" and "soil 2"). The dependent variables are of continuous type and there are nine in number, representing the values of the chemical element concentrations analysed in the study: calcium, magnesium, iron, copper, cadmium, chromium, nickel, lead and zinc, relative to the type of mushrooms studied and the area from which they were collected (Figure 1).

The multivariate analysis of the variance (MANOVA) was the most suitable statistical technique for this experiment to separate and test the significance of the effects caused by the unilateral and simultaneous action of the two factors on dependent variables.

Although the assumptions on the parametric test are fulfilled, especially the multivariate normality, the independence of the data and the homogeneity of the covariant at different levels of the factors, there was still a problem related to the low number of values relative to each sampled subgroup, which could create a low confidence in interpreting the estimated results. Thus, we applied the multivariate analysis of variance using bootstrap approach, due to the resampling technique [8] with minimal assumptions [7].

In our study we found very significant effects $(\mathrm{p}<$ 0.001 ) for both factors and also a very significant interaction $(p<0.001)$ between the type of mushrooms and the soil from which it was harvested at a level of significance $\alpha=0.05$.

In the situation where we had achieved significant effects it was important to continue the statistical analysis by post-hoc tests to verify which of the dependent variables and what level of factor are responsible for the level of significance obtained above in the multivariate case. So, we treated each dependent variable in relation to both factors through the 2-way analysis of variance (ANOVA) to compare the differences obtained between the averages of the dependent variable relative to the levels of the two factors. 

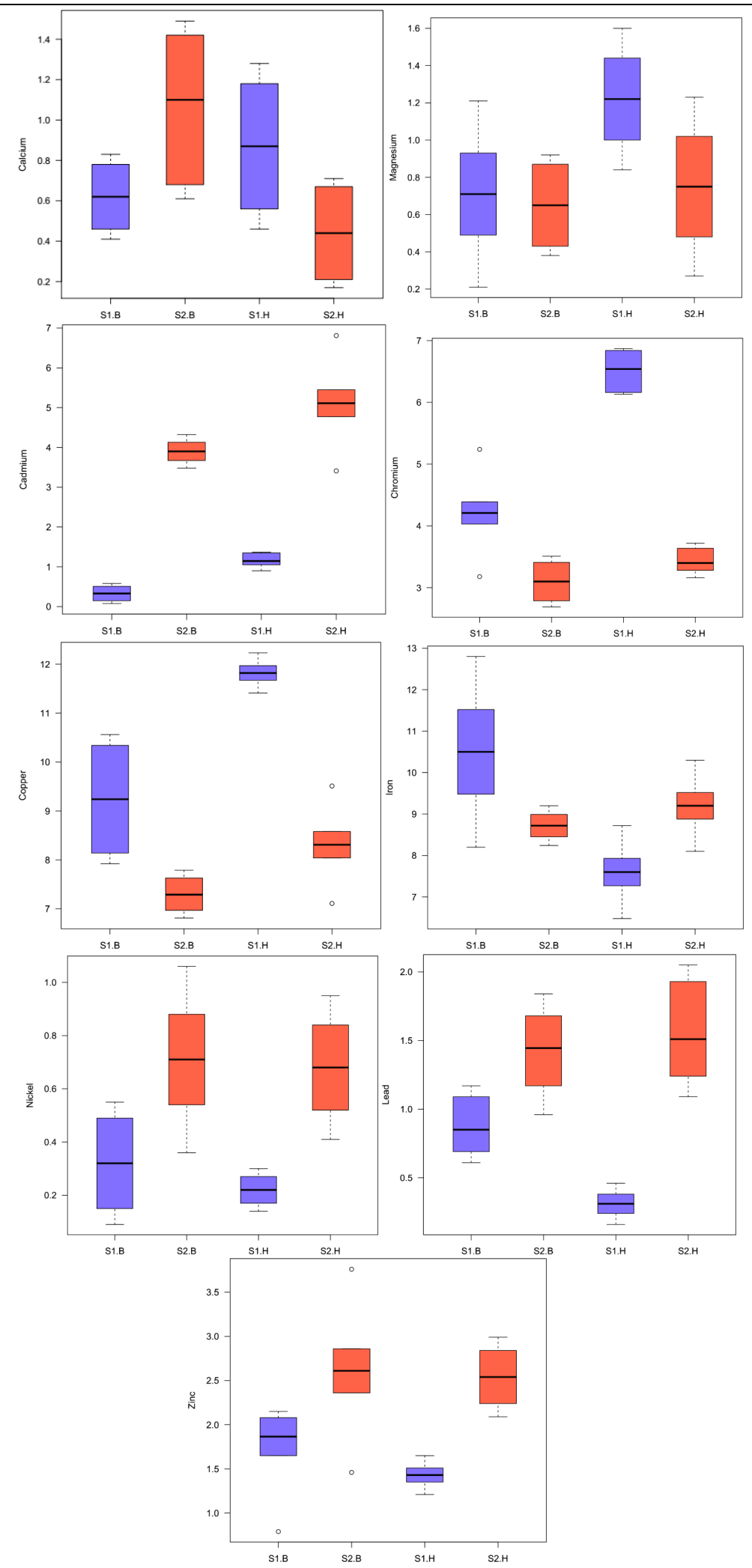

Figure 1.

Box plots considering the relation between the analysed chemical element (calcium, magnesium, cadmium, chromium, copper, iron, nickel, lead, zinc) and mushroom species from both soils ( $\mathrm{S} 1 . \mathrm{B}=$ Boletus $s p$. in soil 1, $\mathrm{S} 2 . \mathrm{B}=$ Boletus $s p$. in soil 2, $\mathrm{S} 1 . \mathrm{H}=$ Hymenochaete $s p$. in soil 1, $\mathrm{S} 2 . \mathrm{H}=$ Hymenochaete $s p$. in soil 2

In relation to the first factor, there were extremely significant differences noted between the two soils only for copper $(p<0.001)$, cadmium $(p<0.001)$, chromium $(\mathrm{p}<0.001)$, nickel $(\mathrm{p}<0.001)$ and zinc $(p<0.001)$. in relation to the second factor, significant differences were observed between the two types of 
fungus only at magnesium $(p=0.026)$, iron $(p=0.006)$, copper $(\mathrm{p}<0.001)$, cadmium $(\mathrm{p}<0.001)$, chromium $(\mathrm{p}<0.001)$ and lead $(\mathrm{p}=0.07)$. Also, a significant interaction between the area factor and the fungus factor was observed only in calcium $(p=0.001)$, iron $(\mathrm{p}<0.001)$, copper $(\mathrm{p}=0.014)$, chromium $(\mathrm{p}<$ $0.001)$ and lead $(\mathrm{p}=0.007)$.

To explain the differences between the averages of the samples for various chemical elements depending on the factor area we conducted a separate statistical analysis. We introduced a new variable in the statistical study that represents the concentration of chemical element for each area from which the mushrooms studied were collected.

In order to demonstrate an influence of soil copper on the mushrooms Boletus, we performed t-student and for $\mathrm{p}<0.001$ the average concentrations (noted with m) measured in relation with the two soils $\left(m_{1}=88.3\right.$ and $m_{2}=63.21$ ) are extremely significance (Figure 2 ). Also, a significant difference was observed at a $\mathrm{p}=$ 0.006 between the concentrations of copper from the Boletus mushrooms relative to the two studied areas $\left(m_{1}=9.24\right.$ and $\left.m_{2}=7.29\right)$. The trend is ascendant, that is, the amount of copper in the soil implies a high amount in Boletus and therefore there is a positive correlation given by the Pearson coefficient 0.95 in soil 1 and 0.88 in soil 2 and the regression lines are suggestive in this case.

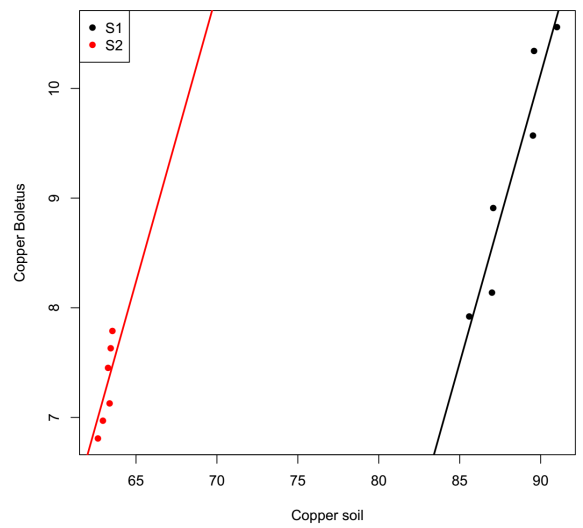

Figure 2.

The correlation between the copper concentrations in the mushroom species determined in both types of soil

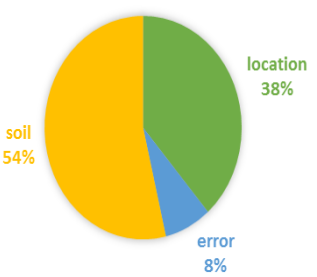

Figure 3.

Proportion of errors without (a) and with (b) influence of copper concentration in soil
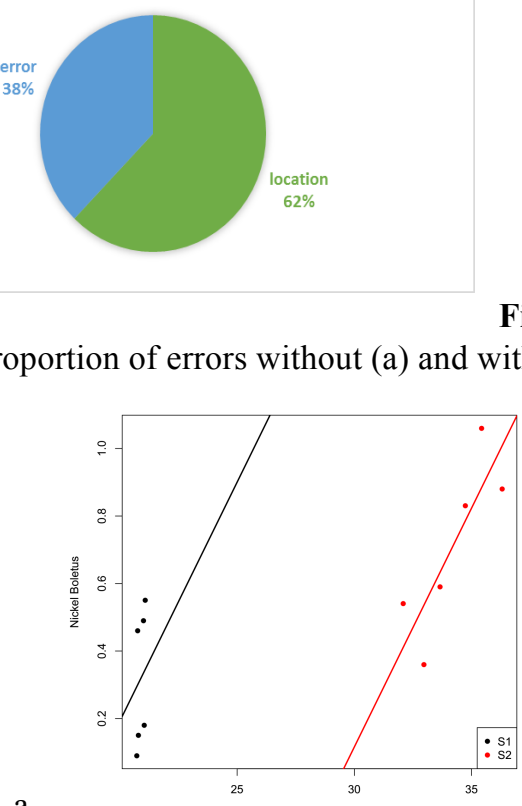

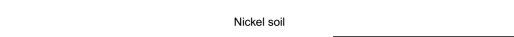

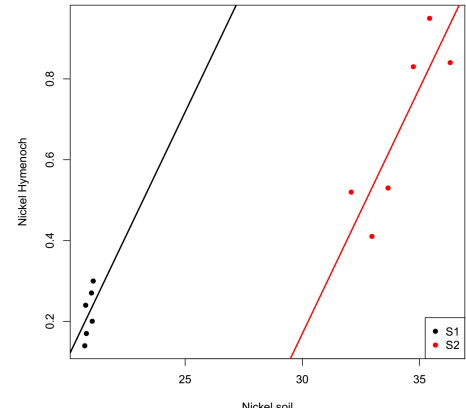

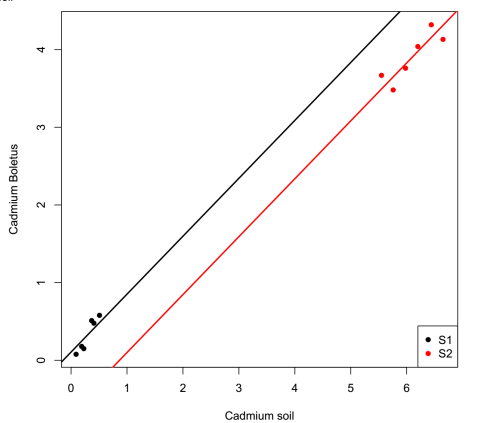

Figure 4.

The correlation between the nickel concentration in the Bolletus sp. (a) and Hymenochaete sp. (b) and cadmium concentration in Bolletus sp. (c) determined in both types of soil 
Thus, we performed the analysis of covariance (ANCOVA) that involves the existence of a covariate (a continuous variable as independent one) that represents copper concentration found in the soil of each area under study to check how much influences the concentration of copper from Boletus samples. As a result of the ANCOVA analysis we can see that the covariate explains $53.7 \% \cong 54 \%$ of the variability of the concentration of copper from Boletus samples to a $\mathrm{p}<0.001$ and an error of only $8 \%$, unlike the situation where the covariate is missing and the error is $38 \%$ (Figure 3 ).

Similarly, we obtain that the concentration of nickelsoil (Figure 4) explains $53.14 \%$ of the variability of the concentration of nickel from the Hymenochaete samples to a $p=0.001$ and $36.7 \%$ of the variability of the concentration of nickel from the Boletus samples to a $\mathrm{p}=0.019$. Also, we find that the concentration of cadmium-soil explains $73.3 \%$ of the variability of the concentration of cadmium from the Boletus samples to a $\mathrm{p}<0.001$.

\section{Conclusions}

There were some variations of trace elements amount between mushroom samples analysed. The calcium and magnesium are typical essential elements for different biota and these metals were usually found in higher concentrations than toxic elements.

In the areas with high degree of soil contamination the mushrooms samples have presented the highest contamination with heavy metals. The highest concentrations of chromium were detected in Hymenochaete rubiginosa samples from the soil 1, lead and cadmium in high concentrations were detected in Hymenochaete rubiginosa samples from soil collected in urban area 2, in change, in Boletus edulis samples from soil 2 were detected the highest amounts of nickel and zinc. An increased contamination with heavy metals of edible species of analysed mushrooms was due to the soil contamination with potential human health threat due to the mushroom's consumption in the alimentation.

According to the statistical analyses results, Boletus edulis is a potential marker of soil pollution for some heavy metals with toxic effect for human healthy such as nickel, cadmium, copper, chromium and iron.

The most likely source of the contamination in both analysed urban areas was the high automobile traffics. Wild-growing mushrooms are valued ingredients of usual food or special dishes in the tradition of many people from those areas, but mushrooms could act as an effective bio-sorbent of toxic metals. Based upon the present safety standards, consumption of those mushrooms that grow in the polluted urban area should be avoided.

\section{References}

1. Farrell M, Perkins WT, Hobbs PJ, Griffith GW, Jones DL, Migration of heavy metals in soil as influenced by compost amendments. Environmental Pollution, 2010; 158 (1): 55-64.

2. Hovanet MV, Dociu N, Dinu M, Ancuceanu R, Morosan E, Oprea E, A comparative physicochemical analysis of Acer platanoides and Acer pseudoplatanus seed oils. Rev Chim (Bucharest), 2015; 66(7): 987-991.

3. Csuros M, Csuros Cs, Environmental sampling and analysis for metals. Ed. Lewis Publishers CRC Press LLC, 2002, 404.

4. Hovanet MV, Oprea E, Ancuceanu RV, Duţu LE, Budura EA, Şeremet O, Ancu I, Morosan E, Wound Healing Properties of Ziziphus jujuba Mill. Leaves. Rom Biotech Lett., 2016; 21(5): 11842-11849.

5. Gîrd CE, Nencu I, Costea T, Duţu LE, Popescu ML, Ciupitu N, Quantitative analysis of phenolic compounds from Salvia officinalis L. leaves. Farmacia, 2014; 62(4): 649-657

6. Sarikurkcu C, Tepe B, Kocak MS, Uren MC, Metal concentration and antioxidant activity of edible mushrooms from Turkey. Food Chem., 2015; 175: 549-555.

7. Árvay J, Tomáša $\mathrm{J}$, Hauptvogl M, Kopernická M, Kováčik A, Bajčan D, Massányi P, Contamination of wild grown edible mushrooms by heavy metals in a former mercury-mining area. $J$ Environ $S c i$ Health B., 2014; 49: 815-827.

8. Falandysz J, Bielawski L, Mercury and its bioconcentration factors in brown birch scaber stalk (Leccinum scabrum) from various sites in Poland. Food Chem., 2007; 105: 635-640.

9. Mititelu M, Ioniţă C, Moroşan E, Research regarding integral processing of mussels from Black Sea. Farmacia, 2014; 62(3): 625-632.

10. Falandysz J, Drewnowska M, Distribution of mercury in Amanita fulva (Schaeff) Secr mushrooms: accumulation, loss in cooking and dietary intake. Ecotoxicol Environ Safe., 2015; 115: 49-54.

11. Falandysz J, Mazur A, Drewnowska M, Kojta AK, Jarzyńska G, Dryżałowska A, Nnorom IC, Mercury in fruiting bodies of dark honey fungus (Armillaria solidipes) and beneath substratum soils collected from spatially distant areas. J Sci Food Agric., 2013; 93: 853-858.

12. Krasińska G, Falandysz J, Mercury in orange birch bolete Leccinum versipelle and soil substratum: Bio-concentration by mushroom and probable dietary intake by consumers. Environ Sci Pollut Res., 2016; 23: 860-869.

13. Ioniţă C, Mititelu M, Moroşan M, Analysis of heavy metals and organic pollutants from some Danube river fishes. Farmacia, 2014; 62(2): 299-305.

14. Mititelu M, Moroşan E, Neacsu SM, Ioniţă EI, Research regarding the pollution degree from Romanian Black Sea coast. Farmacia, 2018; 66(6): 1059-1063.

15. Oprea E, Fărcăşanu IC, Vaccinium corymbosum L. (blueberry) extracts exhibit protective action against cadmium toxicity in Saccharomyces cerevisiae cells. Food Chem., 2014; 152: 516-521. 
16. Fărcăşanu IC, Paraschivescu CC, Ruţă L, Oprea E, Avramescu S, Manipulation of $\mathrm{Ni}^{2+}$ tolerance of Saccharomyces cerevisiae cells: a primary step to bioremediation by removal and recovery of $\mathrm{Ni}^{2+}$ from contaminated waters. Rev Roum Chim., 2008; 53(8): 647-651.

17. Bathke AC, Friedrich S, Pauly M, Konietschke F, Staffen W, Strobl N, Höller Y, Testing mean differences among groups: multivariate and repeated measures analysis with minimal assumptions. Multivar Behav Res., 2018; 53(3): 348-359.
18. Friedrich S, Konietschke F, Pauly M, Analysis of multivariate data and repeated measures designs with the R Package MANOVA.RM. 2017; http://github.com.

19. Drăgoi CM, Olaru OT, Dinu M, Popescu C, Arsene AL, Dune A, Nicolae AC, Ancuceanu RV, Zbârcea CE, Negreș S, Niţulescu GM, Şeremet OC, Characterisation, pharmacotoxicological and biochemical studies on Morus alba L. extract and its fractions. Farmacia, 2018; 66(1): 120-128.

20. Romanian Government, Order of the Ministry of Waters and Forests Regulations regarding the Evaluation of the Environmental Pollution no 765/1997. 